WALlAGE, M. E. 1959. An experimental test of the hypothesis of affinity. Genetica, 29, 243-255.

WAllace, M. E. 1960a. Possible cases of affinity in cotton. Heredity, 14, 263-274.

WALLACE, M. E. 1960b. A possible case of affinity in tomatoes. Heredity, 14, 275-283.

WALLACE, M. E. 1961. Affinity: evidence from crossing inbred lines of mice. Heredity, 16, $1-23$.

WHALEN, R. H. 1965. Genetic segregation in some interspecific and intergeneric hybrids of Lycopersicon and Solanum. Ph.D. thesis, Department of Horticulture, Purdue University. WhALEN, R. H., AND JOHNSON, K. w. 1965. Segregation in hybrids of Lycopersicon esculentum $\times$ L. hirsutum and L. esculentum $\times$ Solanum pennellii. Tomato Genet. Coop. News Letter, 15, 63-64.

\title{
THE ORIGIN OF A DIPLOID " HYBRID" OF CERCOSPORELLA HERPOTRICHOIDES
}

\author{
J. M. L. DAVIES and D. GARETH JONES \\ Department of Agricultural Botany, University College of Wales, Aberystwyth, Wales
}

Received 2.x.69

VARIATION between different isolates of $C$. herpotrichoides has been reported by various workers with respect to morphology (Sprague and Fellows, 1934; Cunningham, 1965; Lange-de la Camp, 1966), growth in liquid cultures (Macer, 1961), and spore prdouction (Glynne, 1953). We have found comparable differences between wild isolates investigated in this laboratory. The sources of variation are not fully elucidated. The following work establishes that hyphal and nuclear fusion contribute to the origin of new variation.

TABLE 1

\begin{tabular}{lll}
\multicolumn{3}{c}{ The "parental " isolates } \\
& $\mathrm{T}$ & $\mathrm{B}$ \\
Host & Wheat & Barley \\
Colour & Black & White \\
Growth & Slow & Fast \\
Spore production & High & Low
\end{tabular}

Two isolates (described in table 1) were co-inoculated on petri dishes containing potato dextrose agar and incubated at $23^{\circ} \mathrm{C}$. until their " hyphal fronts" met. Hyphal tips were taken, from the black and white isolates to check their stability, and from the central portion where the two isolates met. These were then grown on water agar for two days in order to facilitate the spread of individual mycelia as on potato dextrose agar the hyphal tips were compacted together and it was virtually impossible to obtain single hyphal tips. These hyphal tips were then transferred by use of a finely drawn glass rod on to petri dishes containing potato dextrose agar. Tips taken from the black and white portions gave rise to black and white colonies. Of the tips taken from the central portion six produced colonies intermediate in colour between black and white. One of these grey isolates $(T / B 4)$ was investigated in detail.

It appeared probable that the grey colony was a heterokaryon. Unfortunately, when subjected to conditions suitable for sporulation (Jones and 
Davies, 1969), i.e. fluctuating temperatures in a controlled environment cabinet, no spores were produced. Other methods including placing the cultures outside in the autumn, or under near ultraviolet light also failed to induce sporulation, which would have provided a means of testing for heterokaryosis.

$T / B 4$, in fact, showed no sectoring whatsoever, even when grown on extremely different culture media. Neither was there any variation between cultures from single hyphal tips. If $T / B 4$ was a simple heterokaryon it clearly was inordinately stable.

$T / B 4$ was grown in liquid culture and macerated in a blender to single cell fragments. The latter, grown separately, produced grey colonies only. This shows, in fact, that the grey isolate could not have been a straightforward heterokaryon because on maceration black and white colonies would have emerged. This finding strongly suggested the grey isolate to be a diploid " hybrid". Two kinds of evidence confirms this view.

TABLE 2

Nuclear DNA amount (in arbitrary units) each value the mean of 10 nuclei

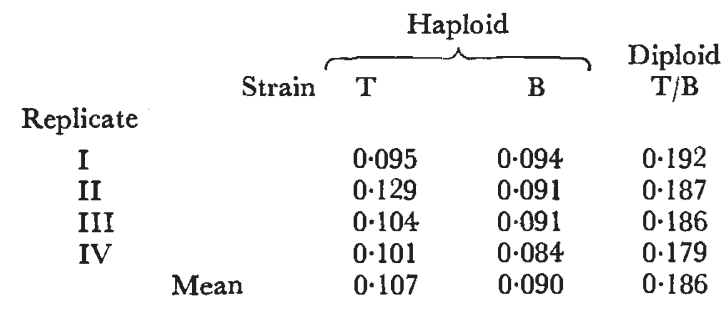

First, when the grey isolates were grown on agar incorporating parafluorophenylalanine, an effective inducer of somatic segregation in diploid Aspergillus (Morpugo, 1961), white colonies arose at lower concentrations of the chemical and black colonies at the higher concentrations. This evidence suggests that a diploid had been formed by fusion of nuclei during a brief heterokaryotic stage.

Second, estimates of nuclear $D \mathcal{N} A$ were made in the presumed diploid and haploid hyphae by Feulgen photometry. For this purpose mycelia of the fungal strains were grown on subbed slides and incubated for a week at $23^{\circ} \mathrm{C}$. The Feulgen staining technique was essentially the one used for higher plants (McLeish and Sunderland, 1961) with certain modifications. Fixation was carried out for 2 hours in Formalin, Acetic Acid Alchohol, $(5: 5: 90)$ and brought into water through the alcohol series; hydrolysis was carried out for 12 minutes in $\mathrm{N} \mathrm{HCl}$ at $60^{\circ} \mathrm{C}$. The preparations were mounted in glycerol and stored in a refrigerator at $4^{\circ} \mathrm{C}$. until required.

Nuclear density measurements were estimated on a Vickers M85 Microdensitometer. The nuclei were examined on a $100 \times$ oil immersion objective and spot-density measurements were carried out at $565 \mathrm{~nm}$. rather than by use of the scanning method which tended to give quite variable results due to the inclusion in the masking area of the background cytoplasm. Despite the very small size of nuclei the densitometer readings are remarkably consistent (table 2). They provide compelling evidence for the diploid status of the " hybrid". Indeed the haploid/diploid values are very close (1 : 1.94) to the expected $1: 2$ ratio. To our knowledge this is the first record of the 
usefulness of Feulgen photometry for comparing nuclear DNA values in micro-organisms.

Considered altogether the evidence clearly points to hyphal fusion followed by nuclear fusion to give rise to a diploid "hybrid". To what extent the process is of significance to the pathogenicity of the fungus has yet to be determined.

\section{REFERENGES}

cunningham, P. c. 1965. Cercosporella herpotrichoides Fron on Gramineous hosts in Ireland. Nature, Lond., 207, 1414-1415.

GlynNe, M. D. 1953. Production of spores by Cercosporella herpotrichoides. Trans. Br. mycol. Soc., $36,46-51$.

JONES, D. G., AND DAVIES, J. M. L. 1969. A comparison of field inoculation methods with Cercosporella herpotrichoides (Fron) on Spring Barley. 7. Agric. Sci., Camb. (In press.)

LANGE-DE LA CAMP, M. 1966. Die Wirkungsweise von Cercosporella herpotrichoides Fron dem Gregor der Halmbruchkraukeit des Getreides I. Feststellung der Kraukheit. Beschaffenheit und Infectinsweise ihres Gregers. Phytopath. Z., 55, 34-66.

MACER, R. C. F. 1961. Saprophytic colonization of wheat straw by Cercosporella herpotrichoides Fron and other fungi. Ann. appl. Biol., 49, 152-164.

MCLEISH, J., AND SUNDERLAND, N. 1961. Measurements of deoxyribosenucleic acid DNA in higher plants by Feulgen photometry and Chemical methods. Exp. Cell Res., 24, 527-540. MORPUGO, G. 1961. Somatic segregation induced by para-fluorophenylalanine. Aspergillus Newsletter, 2, 10.

SPRAGUE, R., AND FELlows, H. 1934. Cercosporella foot rot of winter cereals. Tech. Bull. U.S. Dept. Agric., No. 428. 